\title{
Comparative study of pap smear and microbiological pattern in bacterial vaginosis
}

\author{
Girishma J. ${ }^{1 *}$, Rupakala B. M. ${ }^{\text {, }}$, Sunil Chavan ${ }^{2}$
}

\begin{abstract}
${ }^{1}$ Department of Obstetrics and Gynecology, ${ }^{2}$ Department of Microbiology, Rajarajeswari Medical College and Hospital, Bangalore, Karnataka, India
\end{abstract}

Received: 02 January 2018

Accepted: 31 January 2018

\author{
*Correspondence: \\ Dr. Girishma J., \\ E-mail: girishma.j@gmail.com
}

Copyright: (c) the author(s), publisher and licensee Medip Academy. This is an open-access article distributed under the terms of the Creative Commons Attribution Non-Commercial License, which permits unrestricted non-commercial use, distribution, and reproduction in any medium, provided the original work is properly cited.

\section{ABSTRACT}

Background: Bacterial vaginosis is the most common cause of vaginal discharge among women in reproductive age group. It is characterized by an increased vaginal $\mathrm{pH}$ and loss of normal lactobacilli and overgrowth of anaerobes like Gardnerella vaginalis and other gram-negative rods. Purpose of this study is to compare the characteristics of pap smear and microbiological pattern in patients with abnormal vaginal discharge.

Methods: The study was conducted in the Department of Gynecology and Obstetrics of Rajarajeswari Medical College and Hospital (RRMCH) Bangalore, India. All patients with vaginal discharge were included in the study. Vaginal discharge samples were sent to gram staining, culture and pap smear examination.

Results: Of the 52 patients, 18 patients (34.6\%) showed positive for bacterial vaginosis according to Nugent's score. Of the 18 patients with positive Gram stains, 8 of them were positive for bacterial vaginosis according to pap's smear $(44 \%)$ and 10 had negative pap smears. In our study, of the 18 patients with positive Gram stains, 14 (77\%) of them were positive for bacterial vaginosis according to culture.

Conclusions: In the present study we found out that correlation of gram stain and pap smear was $44 \%$ whereas correlation of gram stain and culture was $77 \%$. Hence, we conclude that gram stain and culture are preferred for the diagnosis of bacterial vaginosis rather than the pap smear evaluation.

Keywords: Bacterial vaginosis, Culture, Gram stain, Pap smear

\section{INTRODUCTION}

Bacterial vaginosis reflects a shift in normal vaginal flora from lactobacilli dominant to mixed flora including Gardnerella vaginalis, mycoplasmas and anaerobes such as Mobiluncus, Peptostreptococcus and Prevotella.

Although Gardnerella and anaerobic organisms can be found in normal vaginal flora, their concentration increases several-fold in women with bacterial vaginosis concurrent with a marked decrease in lactobacilli. Because of the inability to find a transmissible agent, bacterial vaginosis has not been classified as an STI. Currently bacterial vaginosis is described as a sexually associated infection rather than a true sexually transmitted infection. ${ }^{1}$ Bacterial vaginosis is the most common cause of vaginal discharge and malodor. ${ }^{2}$

Most of the patients are asymptomatic. Some patients show symptoms like increase in white discharge which appears homogeneous, is low in viscosity and evenly coats the vaginal mucosa and there is characteristic vaginal odor which smells like a fish. The patients may also experience itching and burning in the vaginal area.

Pap smear is a routine procedure done for cytological screening of cervical cancer. ${ }^{3}$ It can also be used as a diagnostic test for bacterial vaginosis. 
This study is done to compare the characteristics of Pap smear and microbiological pattern among patients with abnormal vaginal discharge.

A polymicrobial superficial vaginal infection involving loss of the normal lactobacilli and overgrowth of anaerobes, such as Gardnerella vaginalis, Bacteroides, Mycoplasm hominis, Mobiluncus and Peptostreptococcus is recognized as bacterial vaginosis. ${ }^{4}$ There is increase in vaginal ph (>4.5) due to decrease in lactobacilli. Bacterial vaginosis was first described by Gardner and Dukes.

Bacterial vaginosis is a common and complex clinical syndrome that reflects abnormal vaginal flora and is poorly understood. It has been variously named and former terms include Haemophilus vaginitis, Corynebacterium vaginitis, Gardnerella or anaerobic vaginitis, and nonspecific vaginitis. The vaginal flora's symbiotic relationship shifts to one in which there is over growth of anaerobic species including Gardnerella vaginalis, Bacteroides, Mycoplasm hominis, Mobiluncus and Peptostreptococcus. Bacterial vaginosis is also associated with significant reduction or absence of the normal hydrogen peroxide producing Lactobacillus species. $^{5}$

Bacterial vaginosis is the most common cause of abnormal vaginal discharge in women of reproductive age. ${ }^{6}$ The cause is unknown. Bacterial vaginosis though closely related to sexual intercourse it is not termed as a sexually transmitted disease because of its high prevalence in sexually inactive women. ${ }^{7}$ The importance of bacterial vaginosis is that, it is associated with pelvic inflammatory diseases, complications of pregnancy. Women with bacterial vaginosis are prone to HIV infections. ${ }^{8}$ Therefore diagnosis of bacterial vaginosis becomes important.

Risk factors include oral sex, douching, black race, cigarette smoking, sexual intercourse during menstruation, intrauterine device, early age of sexual intercourse, new or multiple sexual partners, sexual activity with other women. ${ }^{5}$

The objective of this study was to compare the characteristics of Pap smear and microbiological pattern in bacterial vaginosis.

\section{METHODS}

The study was conducted for a period of 2 months in the Department of Gynecology and Obstetrics of Rajarajeswari Medical College and Hospital (RRMCH) Bangalore, India. Laboratory investigations will be performed in the Department of Microbiology and Department of Pathology RRMCH.

All the patients with vaginal discharge visiting the Department of Obstetrics and Gynecology OPD at RRMCH were included in the study.

\section{Inclusion criteria}

All the patients with vaginal discharge between the age of 18-45 years were included.

\section{Exclusion criteria}

Pregnancy and vaginal bleeding.

\section{Collection of sample}

After a written informed consent was obtained; brief history, general physical examination and per speculum examination was done by an experienced clinician.

A clean dry sterile Cusco's speculum was inserted, and the characteristics of the vaginal discharge were noted. A sterile cotton swab was used to obtain a cerivcovaginal sample and was sent to Microbiology Department.

Samples for PAP smear were collected using a endocervical brush and wooden spatula, the samples were smeared on a clean glass slide cytofixed and sent to Pathology department.

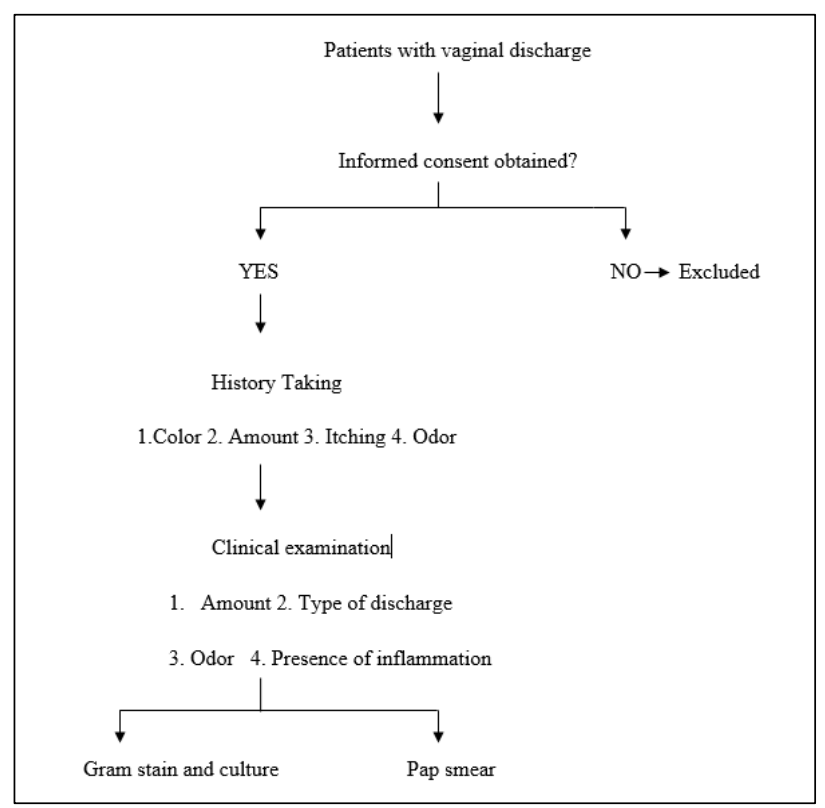

Figure 1: Study Design.

\section{Gram staining and Nugent's scoring system ${ }^{9}$}

Gram-stained slides are examined under oil immersion (x1000). According to Nugent Scoring System, the smears are observed and quantified for the presence of the following morphotypes:

- Large gram-positive bacilli (Lactobacillus morphotypes)

- Small gram variable bacilli (Gardnerella morphotypes) 
- Curved gram negative or gram variable bacilli (Mobiluncus morphotypes)

The number of organisms seen is quantified according to the following scale

- $0=$ No morphotype

- $1+=<1$ organism per field
- $2+=1-4$ organisms per field

- $3+=5-30$ organisms per field

- $4+=\geq 30$ organisms per field

A total numerical score ( $\mathrm{N}$ score) is calculated by summing the scores for the three components as indicated in Table 1.

Table 1: Nugent's Scoring System.

\begin{tabular}{|lllllll} 
Lactobacilli & Score & $\begin{array}{l}\text { Gardnerella, } \\
\text { Bacteroides }\end{array}$ & Score & $\begin{array}{l}\text { Curved gram- } \\
\text { negative bacilli }\end{array}$ & Score & $\begin{array}{l}\text { Sum = n } \\
\text { score }\end{array}$ \\
\hline $4+$ & 0 & 0 & 0 & 0 & 0 & 0 \\
$3+$ & 1 & $1+$ & 1 & $1+$ & 1 & 3 \\
\hline $2+$ & 2 & $2+$ & 2 & $2+$ & 1 & 5 \\
\hline $1+$ & 3 & $3+$ & 3 & $3+$ & 2 & 8 \\
\hline 0 & 4 & $4+$ & 4 & $4+$ & 2 & 10 \\
\hline
\end{tabular}

Table 2: Interpretation Of Nugent's Score.

\begin{tabular}{|ll|}
\hline N score & $\begin{array}{l}\text { Report } \\
0-3\end{array}$ \\
$\begin{array}{l}\text { Gram stain indicates normal bacterial } \\
\text { vaginal flora }\end{array}$ \\
\hline $4-6$ & $\begin{array}{l}\text { Gram stain reveals altered vaginal } \\
\text { flora that is not consistent with } \\
\text { bacterial vaginosis. }\end{array}$ \\
\hline$\geq 7$ & $\begin{array}{l}\text { Gram stain indicates the presence of } \\
\text { bacterial vaginosis. }\end{array}$ \\
\hline
\end{tabular}

\section{Culture}

A cotton-tipped applicator was used to transfer vaginal fluid onto a human blood bilayer medium (HB medium). HB plates were examined for G. vaginalis after 48 and 72 $\mathrm{h}$ of incubation at $37^{\circ} \mathrm{C}$ in $5 \% \mathrm{CO} 2$ in air. G. vaginalis colonies appeared as small beta-hemolytic colonies on HB agar.

The identification was confirmed by their characteristic Gram stain morphology showing small pleomorphic gram-variable rods, fermentation of starch and glucose but not mannitol, the inability to produce green discoloration of chocolate agar, and the inability to produce catalase and oxidase.

The fermentation medium used for identification of $G$. vaginalis consisted of $1 \%$ Proteose peptone no. 3 (Difco Laboratories), $0.3 \%$ meat extract (BBL Microbiology Systems), $0.5 \% \mathrm{NaCl}$, and $1 \%$ Andrade indicator. The $\mathrm{pH}$ was adjusted to 7.1 before the medium was autoclaved. To this base the appropriate sugar $(1 \%)$ and fetal calf serum $(1 \%)$ were added. After all the gram stain smears had been evaluated and the Gram stain diagnoses were made, the results were compared with those of the pap smear.

\section{Pap smear examination}

Pap smears from the transitional zones were evaluated under the Bethesda system guidelines. If there was a filmy background of small coccobacilli, individual squamous cells with a layer of coccobacilli along the margins of the cell membranes, and conspicuous absence of lactobacilli, the smear was evaluated as positive for bacterial vaginosis. ${ }^{10}$

\section{RESULTS}

A total of 52 patients were included in our study. The mean age of the subjects was 31.5 years (Range 18-45 years). Of them the highest were in the age group of 3135 years $(53.8 \%)$ as shown in Table 3 .

Table 3: Age wise distribution of results.

\begin{tabular}{|ll|l|}
\hline Age (years) & No. of cases studied & Percentage $(\%)$ \\
\hline $18-25$ & 10 & 19.2 \\
\hline $26-30$ & 8 & 15.3 \\
\hline $31-35$ & 28 & 53.8 \\
\hline $36-40$ & 5 & 9.61 \\
\hline $41-45$ & 3 & 5.76 \\
\hline Total & 52 & 100 \\
\hline
\end{tabular}

Table 4: Characteristics of vaginal discharge.

\begin{tabular}{|lll|}
\hline Characteristics (colour) & Number & Percentage \\
\hline Grey white & 42 & 80.7 \\
\hline Greenish yellow & 6 & 11.53 \\
\hline yellow & 4 & 7.69 \\
\hline Total & 52 & 100 \\
\hline
\end{tabular}

All the women were suffering from vaginal discharge, which was greyish white discharge in $80.7 \%$ of the 
patients, greenish yellow in $11.53 \%$ of the patients and yellow in $11.69 \%$ of the patients (Table 4 ).

Of the 52 vaginal swabs taken (from ecto and endo cervix), high grade squamous changes was seen in $78.8 \%$ of the patients while $21.2 \%$ of them showed transformation zone (Table 5). 18 patients (34.6\%) showed positive for bacterial vaginosis according to Nugent's score (Table 6).

Of the 18 patients with positive Gram stains, 8 of them were positive for bacterial vaginosis according to pap's smear and 10 had negative pap smears (Table 7).

Table 5: Pap's smear studies.

\begin{tabular}{|lll|}
\hline Changes & Number & Percentage \\
\hline $\begin{array}{l}\text { High grade squamous } \\
\text { change }\end{array}$ & 41 & 78.8 \\
\hline Transformation zone & 11 & 21.2 \\
\hline
\end{tabular}

Table 6: Nugent's score observed in study group.

\begin{tabular}{|lll|}
\hline Nugent's score & No. of patients & Percentage \\
\hline $0-3$ & 32 & 61.5 \\
\hline $4-6$ & 2 & 3.8 \\
\hline $7-10$ & 18 & 34.6 \\
\hline Total & 52 & 100 \\
\hline
\end{tabular}

Table 7: Correlation of gram's stain (Nugent's score) and pap's smear.

\begin{tabular}{lll}
$\begin{array}{l}\text { Gram stain } \\
\text { positive cases }\end{array}$ & $\begin{array}{l}\text { Consistent with } \\
\text { culture }\end{array}$ & $\begin{array}{l}\text { Not } \\
\text { consistent }\end{array}$ \\
\hline 18 & 14 & 4 \\
\hline
\end{tabular}

Of the total 52 patients, 14 samples were culture positive and 18 were gram stain positive (Table 8). 13 patients showed positive for Gardnerella vaginalis (Table 9).

Table 8: Culture positive cases.

\begin{tabular}{|ll|}
\hline Organism & Number \\
\hline Gardnerella vaginalis & 13 \\
\hline Others / misc. & 1 \\
\hline
\end{tabular}

Table 9: Correlation of gram's stain with culture.

\begin{tabular}{|lll}
$\begin{array}{l}\text { Gram stain } \\
\text { positive cases }\end{array}$ & $\begin{array}{l}\text { Consistent with } \\
\text { culture }\end{array}$ & $\begin{array}{l}\text { Not } \\
\text { consistent }\end{array}$ \\
\hline 18 & 14 & 4 \\
\hline
\end{tabular}

\section{DISCUSSION}

Our purpose was to compare the characteristics of Pap smear and microbiological pattern in bacterial vaginosis.

A total of 52 women were enrolled in the study. The age range varied from 18 to 45 years. Middle-aged 31- 35years $(53.8 \%)$ women were affected more. The age range is slightly higher when compared to the study done by Neha Batra et al this may be attributed to the small number of the patients in the study. ${ }^{11}$

Majority of them had come with a history of homogenous grey white discharge $(80.7 \%)$. Others had greenish yellow discharge $(11.53 \%)$ and very few had yellow color discharge (7.69\%). Along with this patient had itching, burning micturition, abdominal pain. Our results correlate with the study done by Neha Batra et al. ${ }^{11}$

41(78.8\%) patients showed high grade squamous change, while $11(21.2 \%)$ showed transformational zone. Which is in accordance with Platz-Christensen et al study. ${ }^{12}$

Majority of the organisms isolated in the present study was $G$. vaginalis. It was consistent with studies like Didier et al and Spiegel CA. ${ }^{13,14}$

Of the 52 patients, 18 patients $(34.6 \%)$ showed positive for bacterial vaginosis according to Nugent's score. Of the 18 patients with positive Gram stains, 8 of them were positive for bacterial vaginosis according to pap's smear (44\%) and 10 had negative pap smears. Present results were consistent with the study done by Schnadig et al. ${ }^{15}$

In the present study, of the 18 patients with positive Gram stains, 14 (77\%) of them were positive for bacterial vaginosis according to culture. This is in correlation with many studies. ${ }^{16,17}$

In the present study we found out that correlation of gram stain and pap smear was $44 \%$ whereas correlation of gram stain and culture was $77 \%$.

Hence gram stain and culture are preferred over pap smear for the diagnosis of bacterial vaginosis.

\section{CONCLUSION}

In our study we found out that correlation of gram stain and pap smear was $44 \%$ whereas correlation of gram stain and culture was $77 \%$. Hence, we infer that gram stain and culture are preferred for the diagnosis of bacterial vaginosis rather than the pap smear evaluation.

Funding: No funding sources

Conflict of interest: None declared

Ethical approval: The study was approved by the Institutional Ethics Committee

\section{REFERENCES}

1. Lentz: Comprehensive Gynecology, 6th ed. Copyright Mosby, An Imprint of Elsevier; 2012:23.

2. Marx J, Hockberger R, Walls R. Marx: Rosen's Emergency Medicine: Concepts and clinical practice, $8^{\text {th }}$ ed. Elsevier; 2014;98. 
3. Sherman ME. Cytopathology. In: K Urman RJ (ed). Blaustein's pathology of the female genital tract, $4^{\text {th }}$ edn. Springer-Verlag: USA; 1994:1097-130.

4. Gardner HL, Dukes CD. Haemophilus vaginalis vaginitis. A newly defined specific infection previously classified "nonspecific" vaginitis. Am J Obstet Gynecol. 1995;69:962-76.

5. Hoffman B, Schorge J, Schaffer J, Halvorson J, Bradshaw K, Corton MM, Williams gynecology $2^{\text {nd }}$ ed. Texas: McGraw Hill; 2012.

6. Morris MC, Rogers PA, Kinghorn GR. Is bacterial vaginosis a sexually transmitted infection? Sex Transm Infect. 2001;77:63-8.

7. Holmes KK. Sexually transmitted diseases. $3^{\text {th }}$ ed. New York: Mc Graw Hill; 1999.

8. Wolrath H, Forsum U, Larsson PG, Boren $\mathrm{H}$. Analysis of bacterial vaginosis-related amines in vaginal fluid by gas chromatography and mass spectroscopy. J Clin Microbiol. 2001;39:4026-31.

9. Nugent RP, Krohn MA, Hillier SL. Reliability of diagnosing bacterial vaginosis is improved by a standardized method of Gram stain interpretation. J Clin Microbiol. 1991;29:297-301.

10. Smith JHF. Bethesda 2001. Cytopathol 2002;13:410 .

11. Batra N, Kumar RV, Alva S, Kariappa TM. Diversity of vaginal microbial communities and role of PAP smear in its detection. Int J Curr Microbiol App Sci. 2014;3(11):596-605.
12. Platz-Christensen JJ, Larson PG, Sundstrom E, Wiqvist N. Detection of bacterial vaginosis in wet mount, Papanicolaou stained vaginal smears and in Gram-stained smears. Acta Obstet Gynecol Scand. 1995;74:67-70.

13. Filho DSC, Diniz CG, da Silva VL. Bacterial vaginosis: clinical, epidemiologic and microbiological features. HU Magazine, Juiz de Fora. 2010;36(3):223-30.

14. Spiegel CA, Amsel R, Holmes KK. Diagnosis of bacterial vaginosis by direct gram stain of vaginal fluid. J Clin Microbiol. 1983:170-7.

15. Schnadig VJ, Davie KD, Shaferc SK. The cytologist and bacteriosis of the vaginal ectocervical area: clues, commas and confusion. Acta Cytol. 1989;33:287-97.

16. Amsel R, Totten PA, Spiegal CA. Nonspecific vaginitis: diagnostic criteria and microbial and epidemiologic associations. Am J Med. 1983;74:1422.

17. Eschenbach DA, Hiller SL, Critchlow C. Diagnosis and clinical manifestations of bacterial vaginosis. Am J Obstet Gynecol. 1988;158(4):819-28.

Cite this article as: Girishma J, Rupakala BM, Chavan S. Comparative study of pap smear and microbiological pattern in bacterial vaginosis. Int $\mathbf{J}$ Reprod Contracept Obstet Gynecol 2018;7:1039-43. 